\title{
Celiac disease
}

National Diabetes Information Clearinghouse (NDIC)

\section{Definitions}

Protein

Defined by National Diabetes Information Clearinghouse (NDIC)

\section{Source}

National Diabetes Information Clearinghouse (U.S.). (2009). The diabetes dictionary. [Bethesda, Md.]: U.S. Dept. of Health and Human Services, National Institutes of Health, National Institute of Diabetes and Digestive and Kidney Diseases, National Diabetes Information Clearinghouse.

The inability to digest and absorb proteins called gluten found in wheat, rye, and barley. Celiac disease causes damage to the lining of the small intestine and prevents absorption of nutrients. Also called celiac sprue, gluten intolerance, and nontropical sprue. 